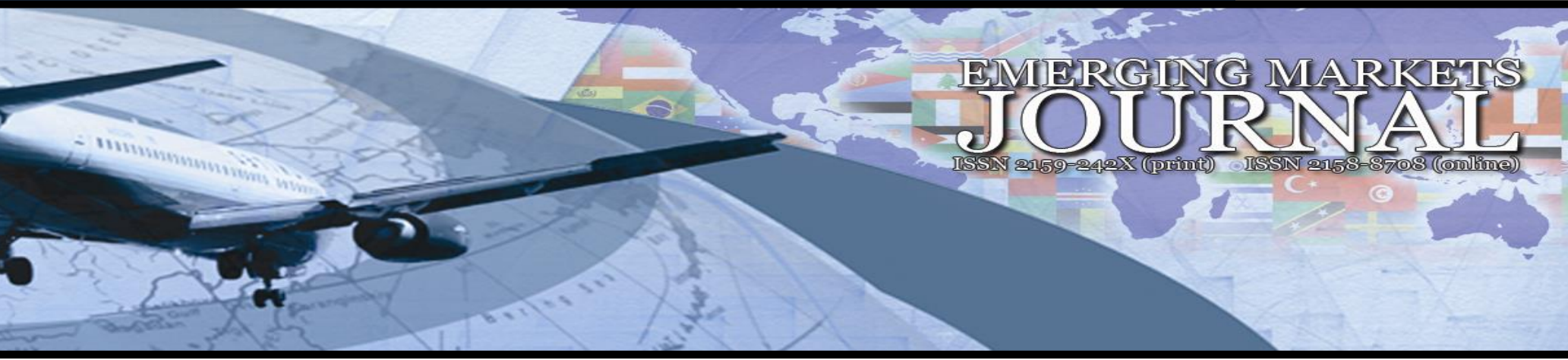

\title{
Information Level Representation of Small and Medium Enterprises (SME) Managers about Securities
}

\section{Ferhat Sayım}

Yalova University, Turkey | $\underline{\text { f sayim@hotmail.com }}$

Volume 9 No 1 (2019) ｜ ISSN 2158-8708 (online) ｜ DOI 10.5195/emaj.2019.178 | http://emaj.pitt.edu |

\begin{abstract}
This research was carried out with private company owners and shareholders-managers in Yalova. These managers were asked about the general approach for the most commonly used securities in the financial system. They were asked to express the level of knowledge they felt. The interviews were conducted face to face with the managers. The level of knowledge expressed by the managers was evaluated on a triple scale. It was examined with various cross tables. Percentages were taken. According to the findings, most owners and shareholders - managers accept that they do not have enough knowledge about the securities used in the financial markets. The lowest level of knowledge is expressed for the derivative products. The highest level of knowledge is expressed for the stock types. As a first step, this study is important in terms of raising awareness on this issue. This research and its results can be used for the development of training and programs for businessman. Also, they can be used in the chambers of commerce and universities.
\end{abstract}

Keywords: SME, Business, Securities, Financial Markets, Finance

* Some findings of this research were presented in the 2.International Symposium on Silkroad Academic Studies, in Turkish language.

\section{$(\mathrm{cc}) \mathrm{BY}$}

New articles in this journal are licensed under a Creative Commons Attribution 3.0 United States License.

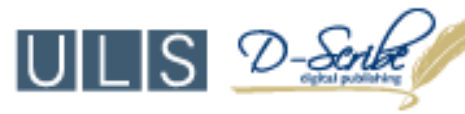

This journal is published by the University Library System of the University of Pittsburgh as part of its D-Scribe Digital Publishing Program, and is cosponsored by the University of Pittsburgh Press. 


\section{Information Level Representation of Small and Medium Enterprises (SME) Managers about Securities}

\author{
Ferhat Sayım
}

\section{Introduction}

A very important part of economic production units is defined as Small and Medium Enterprises (SME). Some of these enterprises can reach a certain size and turnover volume in their cities. Most, however, do not turn into enterprises on a national or global scale. There are many other reasons for this. The level of financial knowledge of business owners and managers is important. How these managers define themselves in financial information is a research topic. The studies in the literature are mostly made on stock market companies. These studies focus on the financial situation and the use of certain instruments or the existence of risks. Another mode of work is for various segments of the population. Financial literacy levels are measured in these studies.

Financial literacy surveys were mostly applied to students and various sections of the population. Apart from the studies on measurement of financial literacy, the following studies have been found. The following publications measure the proximity of businesses to some financial products and concepts.

\section{Literature Review}

In the literature, similar studies were searched. There has not been enough research on businessmen and entrepreneurs. The financial literacy researches are a topic as a close and common research topic. These researches and their results have been examined, but the universe of research is generally students and other sections of the public. At a more conceptual level, the ability of these segments was investigated about evaluating financial institutions and instruments (Coşkun, 2016; Bayram, 2014; Akkaya and Yağl1, 2015).

In a study called Financial Access for SMEs, a general assessment was made, without detailing the financial instruments and institutions. The opportunities for SMEs to benefit not only from the financial market, but also from the state subsidies have been investigated. Regarding the financial markets, issues related to the opening of securities exchanges and the use of bank resources as venture capital have been discussed (Türkonfed - Akbank, 2009).

Bayrakdaroglu, Sar1 and Heybeli published a study in 2013. The study is related to the use of derivative products in financial risk management. Risk perceptions, risk management policies and use of derivative instruments of the enterprises are discussed. According to the findings of the study, most of the companies are affected by the exchange rate risk. Large firms have a tendency to use speculative derivative products. The number of companies using derivative products is low and this is noteworthy. Although companies are aware of derivative products, they are reluctant to use them (Bayrakdaroğlu, Sarı and Heybeli, 2013)

In another study, The Financial Risk Management and Derivative Product Utilization of Enterprises were investigated. It was implemented to companies in Istanbul Stock Exchange (ISE) 100 Index. In this study, the financial risks that the firms are exposed to, the management policies of these risks, the use of derivative instruments and foreign currency positions are examined. What kind of information about the risk management is disclosed to the public was investigated. Financial statements and footnotes of 67 companies in the non-financial sector included in the ISE 100 index were analyzed. According to the study findings, the risks that the firms exposed are credit, liquidity, exchange rate and interest rate risk to in turn. Although the firms stated that they are exposed to the mentioned financial risks, they did not report the management techniques of these risks in detail. The most important result of the study is about use of derivative products. Although the firms in the sample are largescaled, the number of firms using derivative products is low. In addition, it has been seen that there is not enough public information about risk management (Yücel, Mandac1 and Kurt, 2007).

The name of another study in the literature is "Foreign Exchange Hedging Methods and Reasons for Use: ISE Example". One aim of the study is to determine the reasons of the use of foreign exchange derivative products and foreign currency borrowings which are hedging strategies in developing markets. Another purpose is to determine whether these two strategies are alternative or complementary strategies. Based on these objectives, the indicators that can best represent the reasons for hedging is investigated (Demir, 2009).

There is another study in the literature called "Conceptual Investigation of Conjunctive Movements and Investment Decisions of Firms in terms of FirmSecurities Investments". The subject is conceptually dealt with without field work (Benli, 2017).

Based on Trakya Development Agency, Finance Specialization Commission Report, The term Financial Access is used which expresses reasonable supply of quality financial services at reasonable costs. Compared with other countries, Turkey ranks 26 in the world (Yıldırak, n.d.).

Apan and Islamoğlu published a paper named "Finance Management in SMEs". In this study, financing sources of SMEs are sorted as Banks, Venture Capital, Factoring, Financial Leasing, Angel Investor and SME Stock Exchange (Apan and İslamoğlu, 2014).

Yörük has run a research named "Use of Alternative Financial Techniques in Entrepreneurship". In this study, it is tried to determine the level of 
application of financial techniques such as leasing, factoring, forfeiting, franchising and barter in entrepreneurship. The survey was applied to companies of the corporation type without any sector discrimination. At each stage of entrepreneurship, alternative financing techniques which are important in terms of capital and resources was examined. Other than leasing, it was observed that they could not reach to the level of adequate use (Yörük, 2006).

Karamustafa and Karakaya conducted a study in 2002 named "The Bank Preferences, Usage and Satisfaction of Financial Instruments: A Study on Customer of Special Finance Houses in Turkey ". In this study, it has been tried to reveal to what extent the financial products offered by the Private Finance Institutions are known among the customers. The second objective of the study was to determine whether there is a relationship between the products that the customers are aware of and the levels of use. Although the customers who were surveyed were classified according to various criteria such as income level, age and education, there was no classification as entrepreneur or owner (Karamustafa and Karakaya, 2002).

Zor and Akın conducted a study in 2008 named "The Use of Finance Tools in SMEs in the Context of Strategic Projections". In this study, the factors separating SMEs in the use of financial instruments other than shareholders' equity are discussed. Export, legal status and age of business owner were found to be statistically significant, but these variables could not function in stepwise discriminant analysis. Also, the educational level of the owner, the age of the enterprise, the number of personnel and the existence of accounting and finance department were not statistically significant (Zor and Akın, 2008).

Some chambers of commerce may prepare working papers and reports to make SMEs more aware of alternative financing sources (Alptekin, 2007).

\section{Field Study}

This field study was conducted through face-toface interviews with the owners and managers of local firms, the biggest stakeholders of the economy. This field study includes several sub-factors. The volume of the information collected in the study, the need to examine

Table 1:Business Experience Year Frequency

\begin{tabular}{|r|r|r|r|r|}
\hline & $\begin{array}{r}\text { Frequ } \\
\text { ency }\end{array}$ & Percent & \multicolumn{1}{|c|}{ Valid } & $\begin{array}{r}\text { Cumulative } \\
\text { Percent }\end{array}$ \\
\hline Valid 1-10 & 5 & 10,0 & 10,0 & 10,0 \\
$11-20$ & 15 & 30,0 & 30,0 & 40,0 \\
$21-30$ & 19 & 38,0 & 38,0 & 78,0 \\
$31-40$ & 11 & 22,0 & 22,0 & 100,0 \\
& 50 & 100,0 & 100,0 & \\
\hline
\end{tabular}

processing and tabulation of some information require the presentation and dissemination of the results in separate titles. The sub-factors planned during the first set-up of the study constituted the basis of these distinctions.

\section{Importance of Research-Method}

Accounting financial researchers are interested in how business owners and managers define themselves in terms of financial information. The study has a hypothesis. Based on this hypothesis, most firm owners and managers think that financial concepts are important, but they do not know enough about the financial markets and securities used. The general approach of these owners and managers for the most used securities in the financial system has tried to be measured. This measurement was carried out through face-to-face interviews with business owners.

In this study, the level of knowledge that local business owner-managers define for themselves about some securities is discussed. This level of knowledge is not a measure of information that can be measured parametrically. How the surveyed participants stated their level of knowledge about the securities asked was investigated. They are offered three options. $0=\mathrm{I}$ have no knowledge of this. $1=\mathrm{I}$ have a general level of knowledge on this subject $2=$ I have more detailed information, such as Risk, Cost and Earning. The obtained data were subjected to reliability test for nonparametric data evaluated in the statistical program. General information about the study and the findings are presented below.

In this measurement made with various subfactors, data such as turnover size of the enterprises and some personal and educational information of the owner have been obtained. The level of knowledge that SME owners and managers express on securities is also a subfactor. These factors are examined in this study. Information on SMEs, the collected sector and size information as well as the personal information for managers were investigated. It is also examined whether these change the responses. SPSS 17.0 program was used in the analysis.

\section{Scope and Sample}

In the study, the owners and managers of the enterprises, which are defined as legal SMEs and especially related to the chambers of commerce industry, were taken as a sample. The people selected for the sample were obtained from the Chamber of Commerce and the Kosgeb. The interviews were done by filling the questionnaire face to face. In this study, only the businessmen or entrepreneurs were evaluated. Frequency tables are presented below.

\section{Frequency Tables Related to Sampling}

The survey was planned to be made on decision makers in SMEs. Analysis was performed on the sample of 50 owner-managers.

\section{Business Life Experience and Age}

It can be stated that the sample has a balanced distribution in terms of age and years of work experience. Both arguments are divided into 4 subgroups. 
Table 2:Age Frequency

\begin{tabular}{|c|r|r|r|r|}
\hline & $\begin{array}{r}\text { Frequ } \\
\text { ency }\end{array}$ & Percent & Percent & Percent \\
\hline Valid Under 30 & 6 & 12,0 & 12,0 & 12,0 \\
$31-40$ & 9 & 18,0 & 18,0 & 30,0 \\
$41-50$ & 22 & 44,0 & 44,0 & 74,0 \\
$50-60$ & 13 & 26,0 & 26,0 & 100,0 \\
Total & 50 & 100,0 & 100,0 & \\
\hline
\end{tabular}

Table 3:Annual Turnover Frequency

\begin{tabular}{|c|r|r|r|r|}
\hline & Frequency & Percent & $\begin{array}{c}\text { Valid } \\
\text { Percent }\end{array}$ & $\begin{array}{c}\text { Cumulative } \\
\text { Percent }\end{array}$ \\
\hline Valid 1 & 20 & 40,0 & 40,0 & 40,0 \\
2 & 22 & 44,0 & 44,0 & 84,0 \\
3 & 8 & 16,0 & 16,0 & 100,0 \\
Total & 50 & 100,0 & 100,0 & \\
\hline
\end{tabular}

Reliability Testing

The cronbach alpha for the survey is 0.833 . This is a sufficient result to analyze the study.

Table 4:Case Processing Summary

\begin{tabular}{|ll|r|r|}
\hline & & $\mathrm{N}$ & $\%$ \\
\hline Cases & Valid & 50 & 100,0 \\
& Excluded $^{\mathrm{a}}$ & 0 &, 0 \\
& & & \\
& Total & 50 & 100,0 \\
\hline
\end{tabular}

a. Listwise deletion based on all variables in the procedure.

Table 5:Reliability Statistics

\begin{tabular}{|r|r|}
\hline Cronbach's Alpha & N of Items \\
\hline, 833 & 5 \\
\hline
\end{tabular}

Table 6:Item-Total Statistics

\begin{tabular}{|c|c|c|c|c|}
\hline & $\begin{array}{c}\text { Scale } \\
\text { Mean if } \\
\text { Item } \\
\text { Deleted }\end{array}$ & $\begin{array}{c}\text { Scale } \\
\text { Variance } \\
\text { if Item } \\
\text { Deleted }\end{array}$ & $\begin{array}{c}\text { Corrected } \\
\text { Item- } \\
\text { Total } \\
\text { Correlatio } \\
\mathrm{n}\end{array}$ & $\begin{array}{c}\text { Cronbach' } \\
\text { s Alpha if } \\
\text { Item } \\
\text { Deleted }\end{array}$ \\
\hline $\begin{array}{l}\text { (Bond Types, } \\
\text { Repo ....) }\end{array}$ & 3,160 & 4,872 & ,738 & ,770 \\
\hline $\begin{array}{l}\text { (Asset Backed } \\
\text { Securities, Sukuk } \\
\text {...) }\end{array}$ & 3,140 & 4,980 & ,597 & ,810 \\
\hline (Stock Types ....) & 3,040 & 5,019 &, 538 & 830 \\
\hline $\begin{array}{l}\text { (Type A-B etc. } \\
\text { Investment Fund } \\
\text {....) }\end{array}$ & 3,320 & 5,079 & ,661 & ,792 \\
\hline $\begin{array}{l}\text { (Derivative } \\
\text { Products ....) }\end{array}$ & 3,740 & 5,258 & ,658 & ,794 \\
\hline
\end{tabular}

\section{Findings}

\section{Annual Turnover Factor}

The sample was measured in 8 different categories in terms of turnover range. The sample was examined in three groups. These groups are expressed in tables as 1-2-3. Group 1 consists of company representatives with annual turnover up to 1 million TL and it includes 20 people. Group 2 consists of company representatives with a turnover in the range of 1 to 8 Million TL and consists of 22 people. Group 3 includes company representatives with a turnover of more than 8 million TL and consists of 8 people.

The answers to the questions were evaluated. Especially the Group 1 and Group 2 turnover level hierarchical order are reflected in the level of knowledge about these securities. In other words, company representatives with more turnovers feel more informed. Although Group 3 sees itself more informed than the first group, they think that the level of knowledge for some types of securities is lower than Group 2. Derivatives were the financial instrument in which all groups felt themselves least knowledgeable. 
Table 7: (Bond Types, Repo ....)- Annual Turnover Crosstabulation

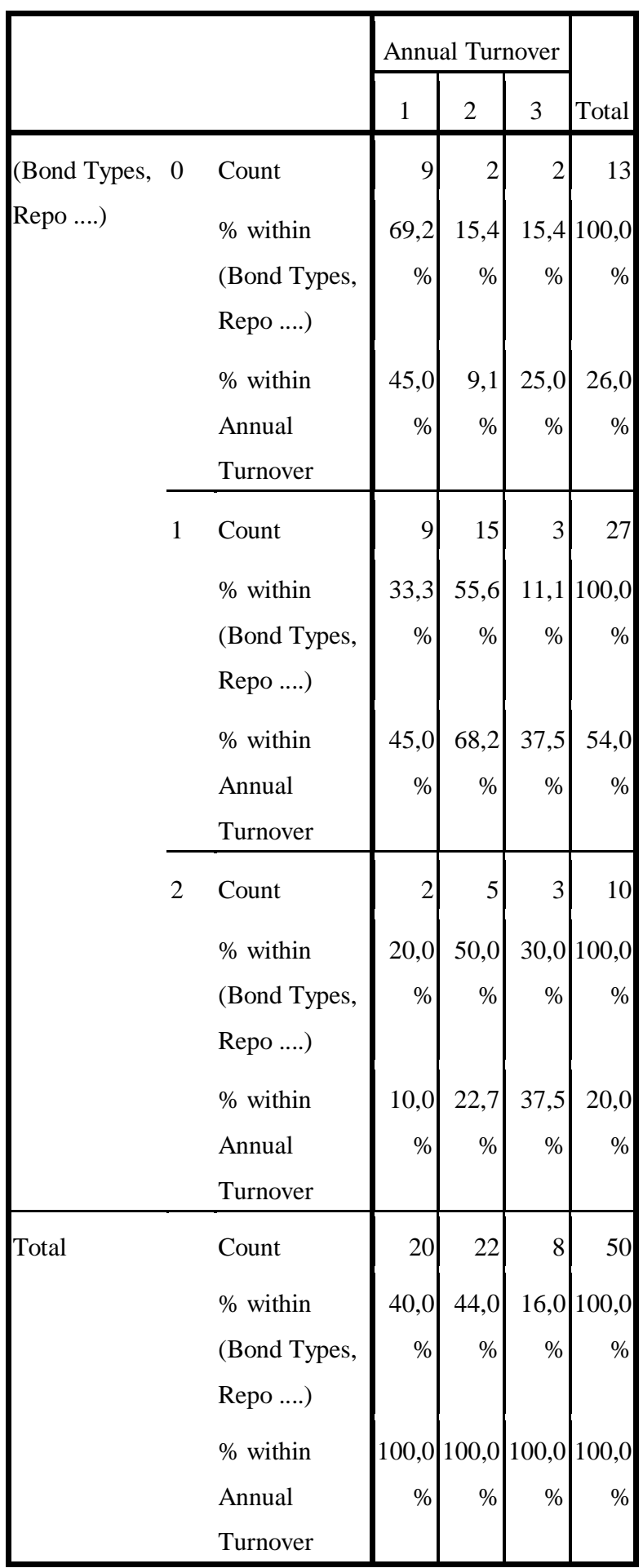

Business people felt themselves knowledgeable at basic level in the type of financial bond. In total, the percentage of those who have no knowledge remains at $26 \%$ while $54 \%$ stated that they are knowledgeable at basic level. In total, $20 \%$ of the businessmen stated that they had good knowledge about this issue. In this case, $80 \%$ defines the level of knowledge as little or no. The rate of those who do not know about it in the lowest annual turnover is high.

Table 8: (Asset Backed Securities, Sukuk ....) - Annual Turnover Crosstabulation

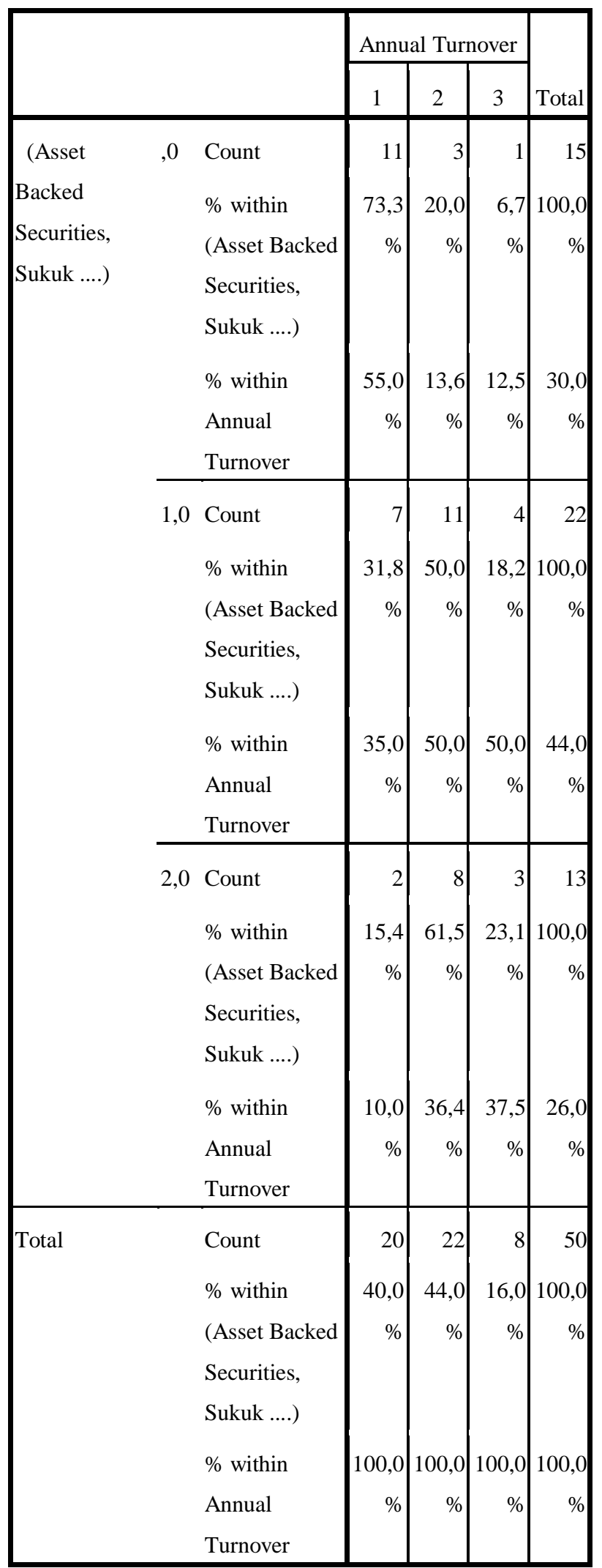


The percentage of those who have no knowledge in this type of securities is $30 \%$ and $44 \%$ is knowledgeable at the basic level. In total, $26 \%$ of businessmen stated that they had a good level of knowledge on this subject. In this case, $74 \%$ describe the level of knowledge as little or no. The lowest rate of those who define themselves as unfamiliar is $55 \%$.

Table 9: (Stock Types ....)- Annual Turnover Crosstabulation

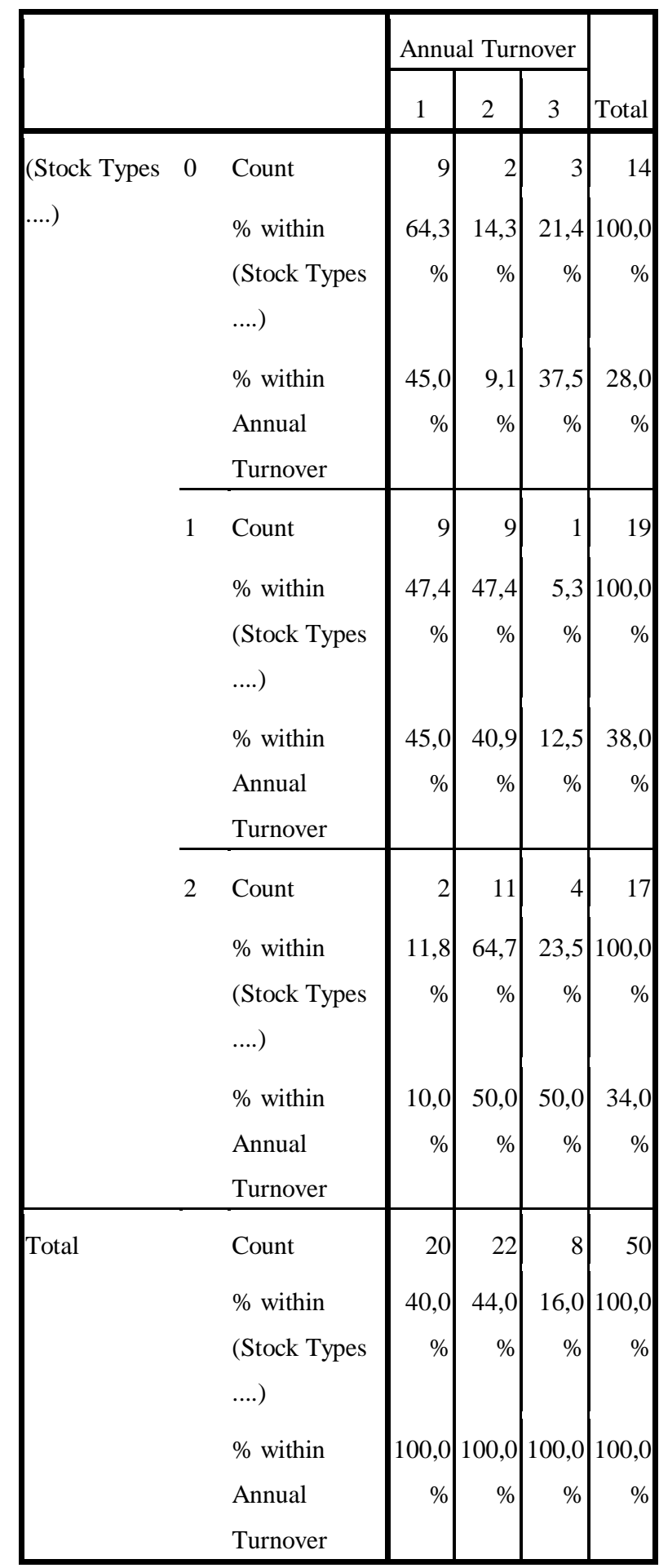

The percentage of those who have no knowledge in this type of securities is $28 \%$ and $38 \%$ of them are at a basic level. In total, $34 \%$ of businessmen stated that they had a good level of knowledge on this issue. In this case, $66 \%$ define the level of knowledge as little or no. The ratio of those who define themselves as unfamiliar is the highest with $45 \%$ in the group of lowest annual turnover. 
Table 10: (Type A-B etc. Investment Fund ......) Annual Turnover Crosstabulation

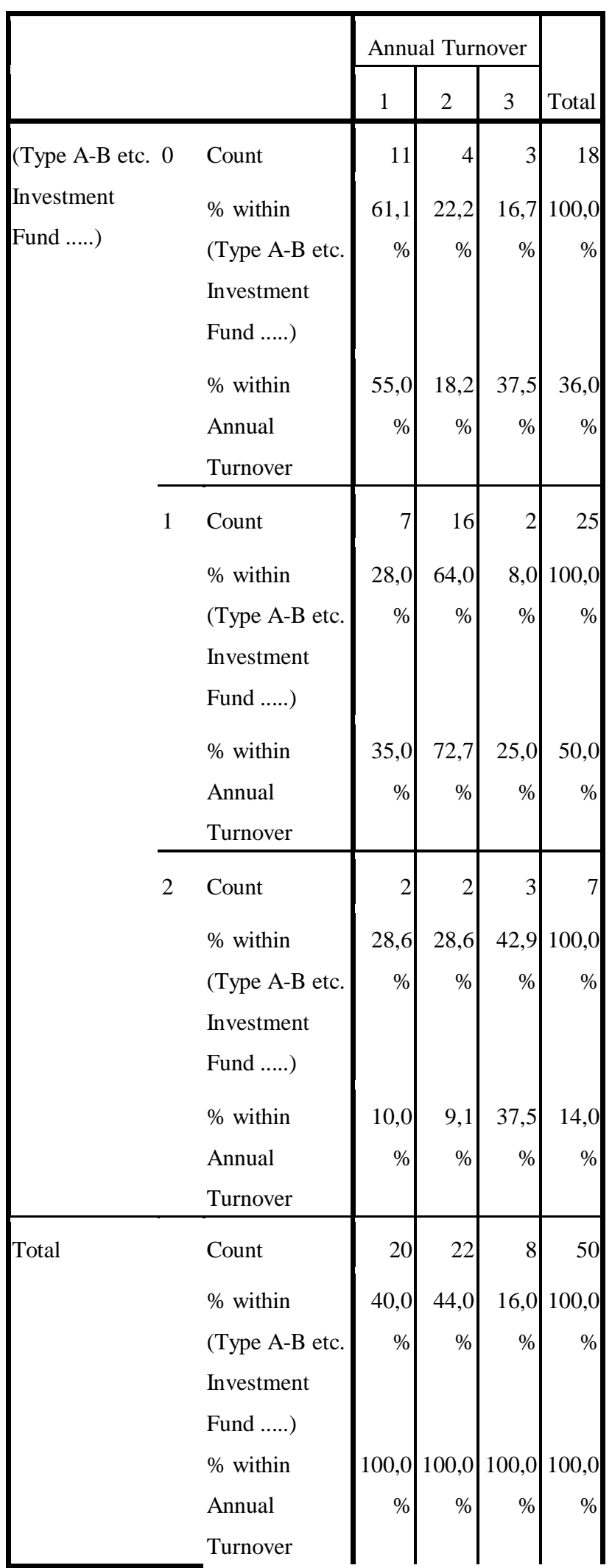

The ratio of those who have no knowledge in this type of securities was $36 \%$. 50\% stated that they are knowledgeable at basic level. In total, only $14 \%$ of businessmen stated that they had a good level of knowledge on this issue. In this case, $86 \%$ define the level of knowledge as little or no. The ratio of those who define themselves as unfamiliar is the highest with $55 \%$ in the group of lowest annual turnover. 
Table 11: (Derivative Products....)- Annual Turnover Crosstabulation

\begin{tabular}{|c|c|c|c|c|c|}
\hline & & Annu & al Turı & hover & \\
\hline & & 1 & 2 & 3 & Total \\
\hline (Derivative 0 & Count & 19 & 13 & 4 & 36 \\
\hline Products & $\%$ within & 52,8 & 36,1 & 11,1 & 100,0 \\
\hline ....) & (Derivative & $\%$ & $\%$ & $\%$ & $\%$ \\
\hline & Products ....) & & & & \\
\hline & $\%$ within & 95,0 & 59,1 & 50,0 & 72,0 \\
\hline & Annual & $\%$ & $\%$ & $\%$ & $\%$ \\
\hline & Turnover & & & & \\
\hline 1 & Count & 1 & 7 & 2 & 10 \\
\hline & $\%$ within & 10,0 & 70,0 & 20,0 & 100,0 \\
\hline & (Derivative & $\%$ & $\%$ & $\%$ & $\%$ \\
\hline & Products ....) & & & & \\
\hline & $\%$ within & 5,0 & 31,8 & 25,0 & 20,0 \\
\hline & Annual & $\%$ & $\%$ & $\%$ & $\%$ \\
\hline & Turnover & & & & \\
\hline 2 & Count & 0 & 2 & 2 & 4 \\
\hline & $\%$ within &, 0 & 50,0 & 50,0 & 100,0 \\
\hline & (Derivative & $\%$ & $\%$ & $\%$ & $\%$ \\
\hline & Products ....) & & & & \\
\hline & $\%$ within &, 0 & 9,1 & 25,0 & 8 , \\
\hline & Annual & $\%$ & $\%$ & $\%$ & $0 \%$ \\
\hline & Turnover & & & & \\
\hline Total & Count & 20 & 22 & 8 & 50 \\
\hline & $\%$ within & 40,0 & 44,0 & 16,0 & 100,0 \\
\hline & (Derivative & $\%$ & $\%$ & $\%$ & $\%$ \\
\hline & Products ....) & & & & \\
\hline & $\%$ within & 100,0 & 100,0 & 100,0 & 100,0 \\
\hline & Annual & $\%$ & $\%$ & $\%$ & $\%$ \\
\hline & Turnover & & & & \\
\hline
\end{tabular}

The level of knowledge about derivative products is much lower. The percentage of those who have no knowledge in this type of securities was $72 \%$. 20\% stated that, they are knowledgeable at basic level. In total, only $8 \%$ of businessmen stated that they had a good level of knowledge on this issue. In this case, $92 \%$ define the level of knowledge as little or no. The ratio of those who define themselves as unfamiliar is the highest with $95 \%$ in the group of lowest annual turnover.

\section{Business Experience Year Factor}

Table 12: (Bond Types, Repo ....)- Business

Experience Year Crosstabulation

\begin{tabular}{|c|c|c|c|c|c|}
\hline & \multicolumn{4}{|c|}{ Business Experience Year } & \multirow{2}{*}{$-\begin{array}{c}\text { Tota } \\
1\end{array}$} \\
\hline & $1-10$ & $11-20$ & $21-30$ & $31-40$ & \\
\hline 0 Count & 3 & 4 & 3 & 3 & 13 \\
\hline$\%$ within & 23,1 & 30,8 & 23,1 & 23,1 & 100 \\
\hline (Bond & $\%$ & $\%$ & $\%$ & $\%$ & $0 \%$ \\
\hline Types, & & & & & \\
\hline Repo ....) & & & & & \\
\hline$\%$ within & 60,0 & 26,7 & 15,8 & 27,3 & 26,0 \\
\hline Business & $\%$ & $\%$ & $\%$ & $\%$ & $\%$ \\
\hline Experience & & & & & \\
\hline Year & & & & & \\
\hline 1 Count & 1 & 7 & 12 & 7 & 27 \\
\hline$\%$ within & 3,7 & 25,9 & 44,4 & 25,9 & 100 \\
\hline (Bond & $\%$ & $\%$ & $\%$ & $\%$ & $0 \%$ \\
\hline Types, & & & & & \\
\hline Repo ....) & & & & & \\
\hline$\%$ within & 20,0 & 46,7 & 63,2 & 63,6 & 54,0 \\
\hline Business & $\%$ & $\%$ & $\%$ & $\%$ & $\%$ \\
\hline Experience & & & & & \\
\hline Year & & & & & \\
\hline 2 Count & 1 & 4 & 4 & 1 & 10 \\
\hline$\%$ within & 10,0 & 40,0 & 40,0 & 10,0 & 100, \\
\hline (Bond & $\%$ & $\%$ & $\%$ & $\%$ & $0 \%$ \\
\hline Types, & & & & & \\
\hline Repo ....) & & & & & \\
\hline$\%$ within & 20,0 & 26,7 & 21,1 & 9,1 & 20,0 \\
\hline Business & $\%$ & $\%$ & $\%$ & $\%$ & $\%$ \\
\hline Experience & & & & & \\
\hline Year & & & & & \\
\hline
\end{tabular}




\begin{tabular}{|ll|r|r|r|r|r|}
\hline Total Count & 5 & 15 & 19 & 11 & 50 \\
& $\%$ within & 10,0 & 30,0 & 38,0 & 22,0 & 100, \\
(Bond & $\%$ & $\%$ & $\%$ & $\%$ & $0 \%$ \\
Types, & & & & & \\
Repo ...) & & & & & \\
\% within & 100,0 & 100,0 & 100,0 & 100,0 & 100, \\
Business & $\%$ & $\%$ & $\%$ & $\%$ & $0 \%$ \\
Experience & & & & & \\
Year & & & & & \\
\hline
\end{tabular}

While $60 \%$ of those with the lowest work experience have no knowledge of this type of securities, the remaining $20 \%$ state that they have only the first level knowledge. Those who have 11-20 years of work experience are more confident about this. 9\% of those with more than 30 years of work experience feel sufficiently informed about this. When the whole sample is taken into account, only $20 \%$ of the SME managers feel that they are well informed in this regard. $80 \%$ agree that the level of knowledge is incomplete.

Table 13: (Asset Backed Securities, Sukuk ....) Business Experience Year Crosstabulation

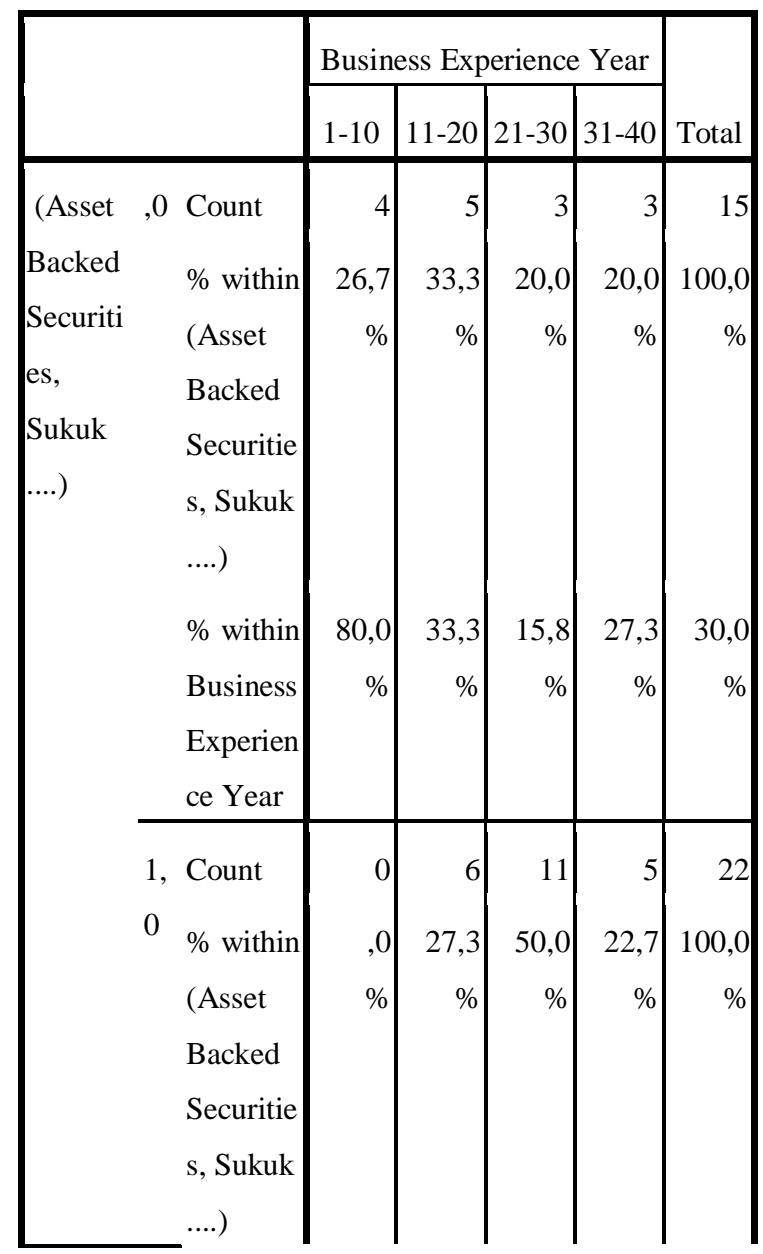

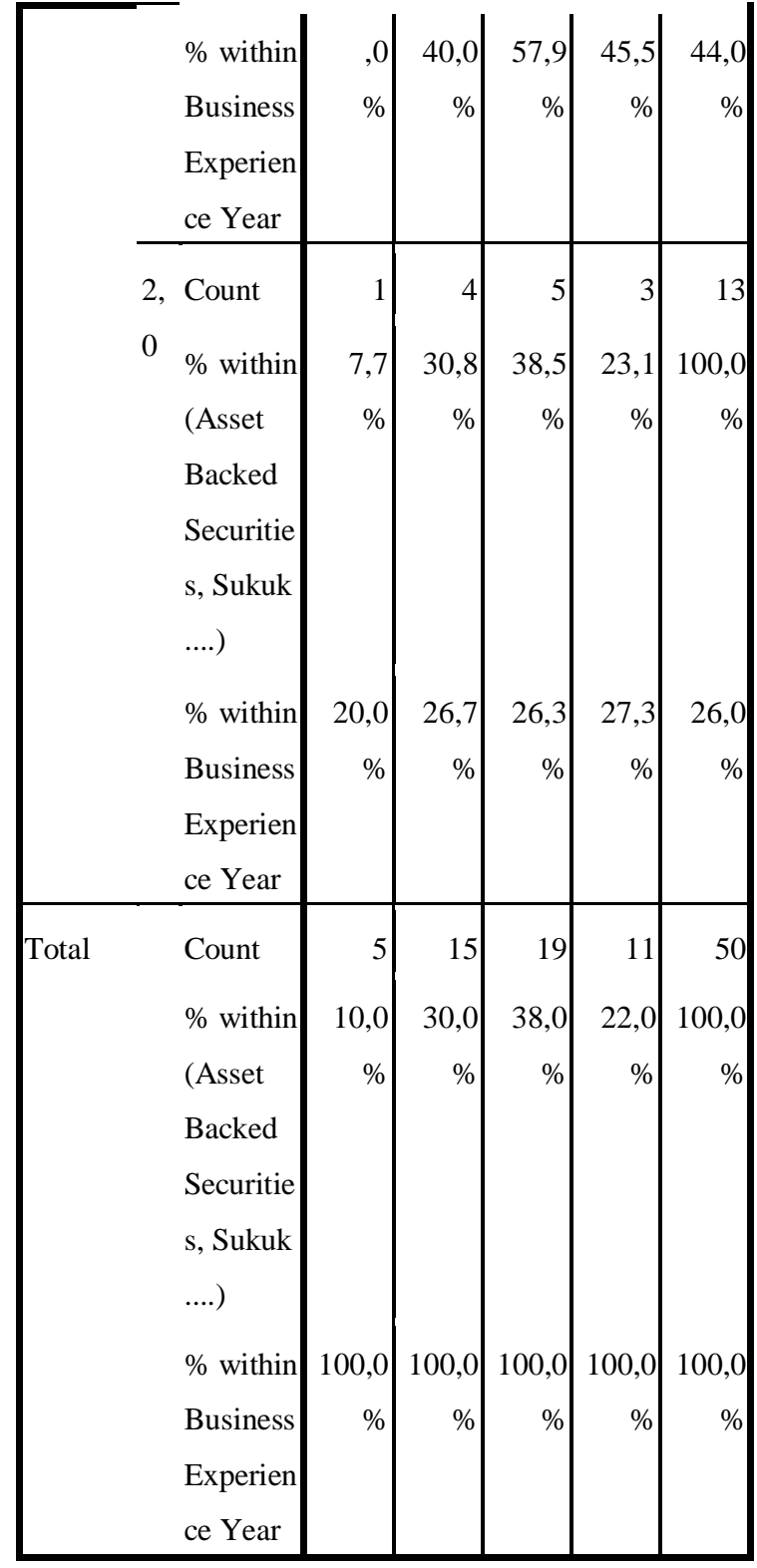

Almost all those with the lowest work experience have no knowledge of this security. As the number of years of experience in business life increases, the proportion of those who feel basic knowledge about this issue is increasing. When the whole sample is taken into consideration, it is seen that $30 \%$ of the managers of the SMEs do not know about it, $44 \%$ have basic knowledge and $26 \%$ of them feel well informed. Thus, $74 \%$ agree that the level of knowledge is incomplete. 
Table 14: (Stock Types ....)- Business Experience Year Crosstabulation

\begin{tabular}{|c|c|c|c|c|c|c|}
\hline & \multicolumn{4}{|c|}{ Business Experience Year } & \multirow[b]{2}{*}{ Total } \\
\hline & & $1-10$ & $11-20$ & $21-30$ & $31-40$ & \\
\hline \multirow{24}{*}{$\begin{array}{l}\text { (Stoc } \\
k \\
\text { Type } \\
\text { S ....) }\end{array}$} & 0 Count & 2 & 2 & 6 & 4 & 14 \\
\hline & $\%$ within & 14,3 & 14,3 & 42,9 & 28,6 & 100,0 \\
\hline & (Stock & $\%$ & $\%$ & $\%$ & $\%$ & $\%$ \\
\hline & Types ....) & & & & & \\
\hline & $\%$ within & 40,0 & 13,3 & 31,6 & 36,4 & 28,0 \\
\hline & Business & $\%$ & $\%$ & $\%$ & $\%$ & $\%$ \\
\hline & Experienc & & & & & \\
\hline & e Year & & & & & \\
\hline & 1 Count & 2 & 5 & 8 & 4 & 19 \\
\hline & $\%$ within & 10,5 & 26,3 & 42,1 & 21,1 & 100,0 \\
\hline & (Stock & $\%$ & $\%$ & $\%$ & $\%$ & $\%$ \\
\hline & Types ....) & & & & & \\
\hline & $\%$ within & 40,0 & 33,3 & 42,1 & 36,4 & 38,0 \\
\hline & Business & $\%$ & $\%$ & $\%$ & $\%$ & $\%$ \\
\hline & Experienc & & & & & \\
\hline & e Year & & & & & \\
\hline & 2 Count & 1 & 8 & 5 & 3 & 17 \\
\hline & $\%$ within & 5,9 & 47,1 & 29,4 & 17,6 & 100,0 \\
\hline & (Stock & $\%$ & $\%$ & $\%$ & $\%$ & $\%$ \\
\hline & Types ....) & & & & & \\
\hline & $\%$ within & 20,0 & 53,3 & 26,3 & 27,3 & 34,0 \\
\hline & Business & $\%$ & $\%$ & $\%$ & $\%$ & $\%$ \\
\hline & Experienc & & & & & \\
\hline & e Year & & & & & \\
\hline \multirow[t]{8}{*}{ Total } & Count & 5 & 15 & 19 & 11 & 50 \\
\hline & $\%$ within & 10,0 & 30,0 & 38,0 & 22,0 & 100,0 \\
\hline & (Stock & $\%$ & $\%$ & $\%$ & $\%$ & $\%$ \\
\hline & Types ....) & & & & & \\
\hline & $\%$ within & 100,0 & 100,0 & 100,0 & 100,0 & 100,0 \\
\hline & Business & $\%$ & $\%$ & $\%$ & $\%$ & $\%$ \\
\hline & Experienc & & & & & \\
\hline & e Year & & & & & \\
\hline
\end{tabular}

When the whole sample is taken into consideration, it is seen that $28 \%$ of the managers of the SMEs do not know about it, $38 \%$ of them feel knowledgeable at the basic level and $34 \%$ of them feel well informed. Thus, $66 \%$ accept that the level of knowledge is incomplete.

Table 15: (Type A-B etc. Investment Fund .....) Business Experience Year Crosstabulation

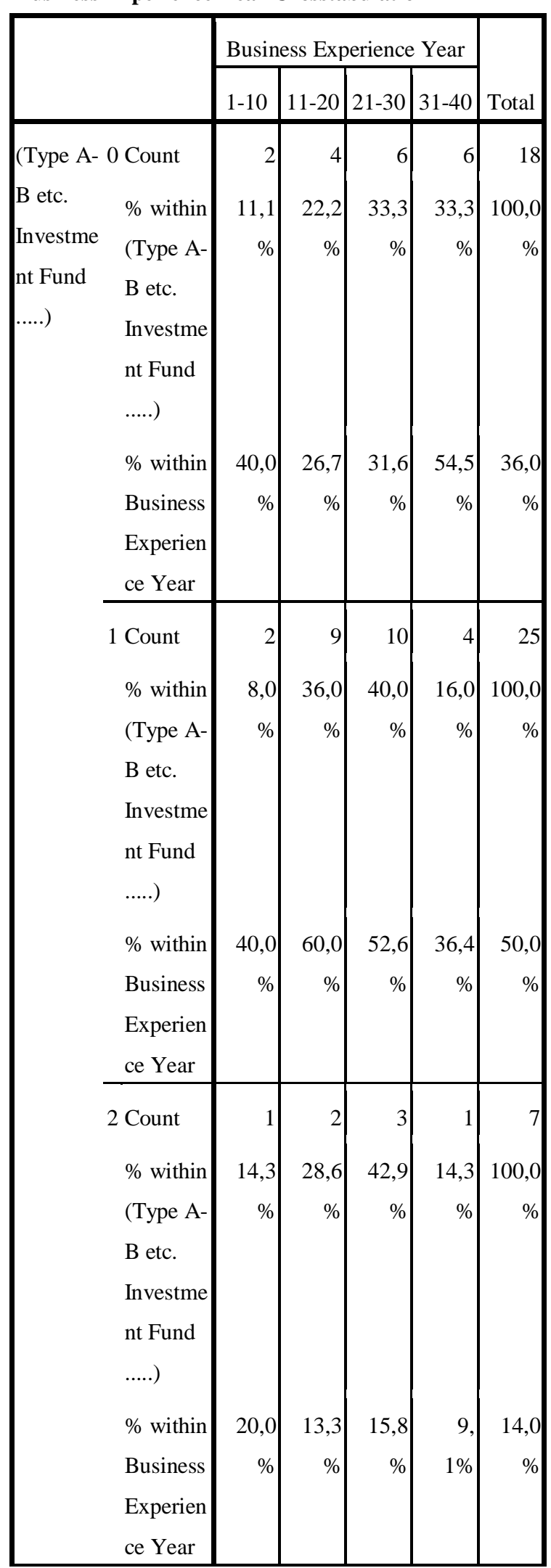




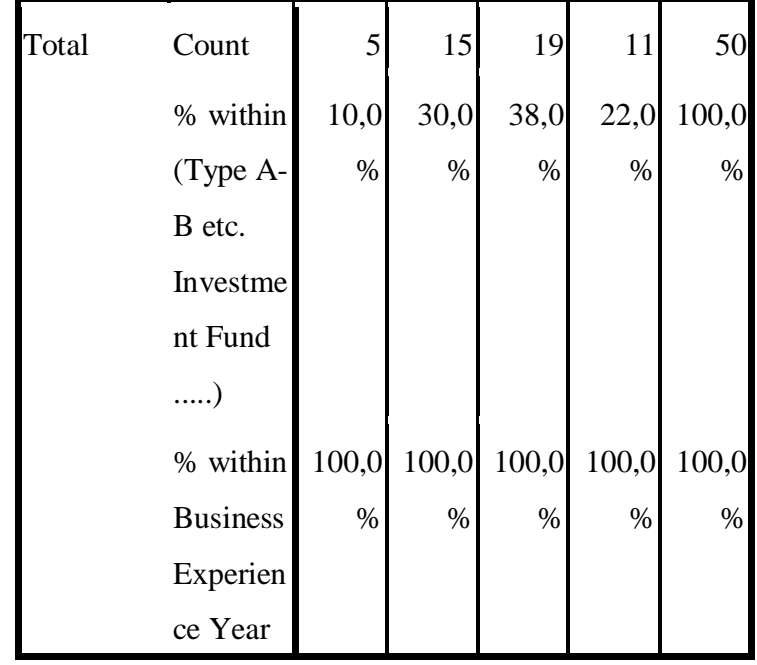

A significant portion of those who have had a work experience of less than 10 years and over 30 years of experience stated that they have no knowledge of these securities. Groups between 11-30 years work experience are more self confident about this issue and their rates are close to each other. When the whole sample is taken into consideration, $36 \%$ of the managers of the SMEs do not know about it, $50 \%$ of them feel at the basic level knowledge and $14 \%$ of them feel well informed. Thus, $86 \%$ accept that the level of knowledge is incomplete.

Table 16: (Derivative Products ....) - Business Experience Year Crosstabulation

\begin{tabular}{|c|c|c|c|c|c|c|}
\hline & \multicolumn{4}{|c|}{ Business Experience Year } & \multirow[b]{2}{*}{ Total } \\
\hline & & $1-10$ & $11-20$ & $21-30$ & $31-40$ & \\
\hline \multirow{16}{*}{$\begin{array}{l}\text { (Derivati } \\
\text { ve } \\
\text { Products } \\
\text {...) }\end{array}$} & 0 Count & 4 & 8 & 17 & 7 & 36 \\
\hline & $\%$ within & 11,1 & 22,2 & 47,2 & 19,4 & 100,0 \\
\hline & (Derivati & $\%$ & $\%$ & $\%$ & $\%$ & $\%$ \\
\hline & ve & & & & & \\
\hline & Products & & & & & \\
\hline & ....) & & & & & \\
\hline & $\%$ within & 80,0 & 53,3 & 89,5 & 63,6 & 72,0 \\
\hline & Business & $\%$ & $\%$ & $\%$ & $\%$ & $\%$ \\
\hline & Experien & & & & & \\
\hline & ce Year & & & & & \\
\hline & 1 Count & 0 & 5 & 2 & 3 & 10 \\
\hline & $\%$ within & 0 & 50,0 & 20,0 & 30,0 & 100,0 \\
\hline & (Derivati & $\%$ & $\%$ & $\%$ & $\%$ & $\%$ \\
\hline & ve & & & & & \\
\hline & Products & & & & & \\
\hline & ....) & & & & & \\
\hline
\end{tabular}

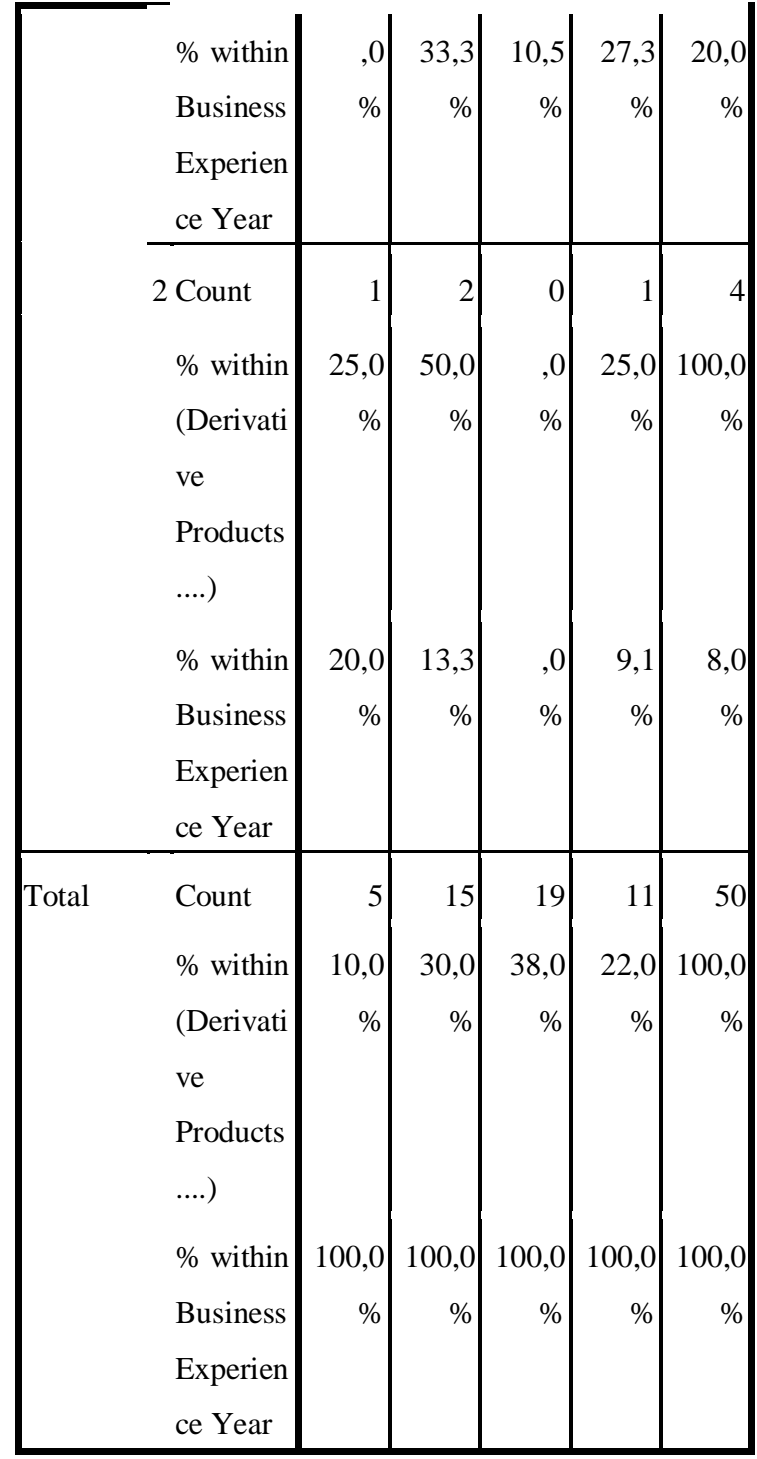

The level of knowledge about derivative products is much lower. When the whole sample is taken into account, $72 \%$ of the company owners do not know about it, $20 \%$ of them have the basic knowledge, only $8 \%$ of them feel well informed. Thus, 92\% accept that the knowledge level is incomplete.

\section{Conclusion and Recommendations}

The rate of those who have no knowledge in the type of mutual funds, such as A-B type, was 36\%. 50\% stated that they are knowledgeable at basic level. In total, only $14 \%$ of businessmen stated that they had a good level of knowledge on this issue. In this case, $86 \%$ define the level of knowledge as little or no. The rate of those who define themselves as unfamiliar is 55\% in the lowest annual turnover group. A significant number of those with 10-year or six-to-30-year-old business experience have no knowledge of these securities. Groups between 11-30 years are more self-confident about this issue and their rates are close to each other.

The level of knowledge about derivative products is much lower. When the whole sample is taken into consideration, $72 \%$ of the company managers feel completely ignorant about this issue, $20 \%$ of them have 
basic knowledge, and only $8 \%$ of them feel well informed. Thus, $92 \%$ define the level of knowledge as little or no. The ratio of those who define themselves as ignorant in the lowest annual turnover group ones is highest with $95 \%$.

Companies with the lowest business life experience and minimum annual turnover are the ones who feel the least knowledgeable. 11-20 years of work experience is more confident in this regard group. Only $9 \%$ of those with a work experience of above 30 years feel sufficiently knowledgeable in this regard. When the whole sample is taken into account, only $20 \%$ of the SME managers feel that they are well informed in this regard. $80 \%$ agree that the level of knowledge is incomplete.

With regard to asset-backed securities, almost the entire lowest work experience group is unaware of these securities. As the number of years of experience in business life increases, the proportion of those who feel basic knowledge about this issue is increasing. The same relationship, with less rigidity, is true also on the increase in turnover. When the whole sample is taken into consideration, it is seen that $30 \%$ of the managers of the SMEs do not know about it, $44 \%$ feel basic knowledge and $26 \%$ of them feel well informed. Thus, $74 \%$ agree that the level of knowledge is incomplete.

The ratio of those who said that they have no knowledge in the type of securities is $28 \%$ and $38 \%$ of them are at the basic level knowledge. In total, 34\% of businessmen stated that they had a good level of knowledge on this issue. In this case, $66 \%$ define the level of knowledge as little or no. The lowest rate of those who define themselves as unfamiliar is $45 \%$. In the group with the least work experience, this rate was $40 \%$.

During the analysis, the level of knowledge that business people feel about the age range and securities is also tabulated and analyzed. As expected in this variable, the situation was parallel with the years of experience in the business life. Although there are some small differentials, it is not necessary to include these tables in the study. The analysis can be summarized as follows. The relationship between the age range and the level of knowledge about securities is observed. A significant number of managers under the age of 30 see themselves as ignorant about securities. The groups that are between the ages of 31-50 are the ones trusting themselves the most. However, in some types of securities, the level of knowledge felt by the age group above 50 is close to age groups between 31 and 50. The group over 50 years of age was the most uninformed about derivative financial instruments.

This study is important in terms of testing the deficiency expressed in the hypothesis and creating awareness on this issue as a first step. This awareness needs to begin and be defined by professional organizations such as chambers of commerce and industries, universities etc. Also, it can be used to determine the need for certification programs to be implemented by institutions. It can also be used to increase interest and to shape the curriculum. In addition, new academic studies on the interaction of fieldwork data with different factors can be made in the future. Again, using this information, the central economic management can use this information to better understand the owners and managers of SMEs, to create policies and to make arrangements.

\section{References}

Alkaya, A., \& Yağlı, İ. (2015, Ekim). Finansal Okuryazarlık - Finansal Bilgi, Davranış ve Tutum: Nevşehir Hacı Bektaş Veli Üniversitesi İ̈BF Öğrencileri Üzerine Bir Uygulama. Uluslararası Sosyal Araştırmalar Dergisi, 8(40), 585-599.

Alptekin, E. (2007). KOBI'ler Alternatif Finansman Kaynakları'nın Farkinda Mi? Retrieved Kasım 12, 2018, from İzmir Ticaret Odas1 Web Sitesi: http://www.izto.org.tr/Portals/0/IztoGenel/Dok umanlar/kobiler_alternatif_finansman_kaynakl arinin_farkindami_e_alptekin_26.04.2012\%20 21-41-56.pdf

Apan, M., \& İslamoğlu, M. (2014, Temmuz). KOBİlerde Finans Yönetimi. International Journal of Science Culture and Sport, 2(Special Issue 1), 208-218.

Bayrakdaroğlu, A., Sarı, B., \& Heybeli, B. (2013). İşletmelerinin Finansal Risk Yönetiminde Türev Ürün Kullanımlarına İlişkin Bir Saha Araştırması: Denizli İli Örneği. Muhasebe ve Finans(Ocak), 57-72.

Bayram, S. S. (2014). Finansal Okuryazarlık ve Para Yönetimi Davranışları: Anadolu Üniversitesi Öğrencileri Üzerine Uygulama. Business \& Management Studies: An International Journal, 2(2), 105-135.

Benli, T. (2017). Konjonktür Hareketler Ve İșletmelerin Yatırım Kararlarının Firma-Menkul Kıymet Yatırımları Açısından Kavramsal İncelemesi. Turkish Journal of Marketing, 2(3), 104-124.

Coşkun, S. (2016, 07 05). Üniversite Öğrencilerinin Finansal Davranış Ve Tutumlarının Belirlenmesi: Finansal Okuryazarlık Algıları Üzerine Bir Araștırma. Insan ve Toplum Bilimleri Araştırmaları Dergisi, 5(7), 22472258.

Demir, S. (2009). Döviz Riskinden Korunma Yöntemleri ve Kullanılma Nedenleri: İMKB Örneği. Muhasebe ve Finansman Dergisi(41), 156-170. 
Karamustafa, O., \& Karakaya, A. (2002, Ekim). Banka Tercihi, Finansal Araçların Kullanımı ve Memnuniyeti: Türkiye'deki Özel Finans Kurumu Müşterileri Üzerine Bir Araştırma. Muhasebe ve Finansman Dergisi(16), 82-96.

Türkonfed - Akbank. (2009, Aralık). Türkonfed. Retrieved Ekim 24, 2018, from Türk Girişim ve İş Dünyası Konfederasyonu: http://www.turkonfed.org/Files/ContentFile/tur konfed-rapor-2009-kobi-c2.pdf

Yıldırak, K. (n.d.). Finans Özel İhtisas Komisyonu Raporu. Retrieved 11 12, 2018, from Trakya Kalınma Ajansı Web Sitesi: https://www.trakyaka.org.tr/upload/Domain/tra kyaka/28062013bkkmQE.pdf

Yörük, N. (2006). Girişimcilikte Alternatif Finansman Tekniklerinin Kullanımı. Uluslararast Girişimcilik Kongresi, Kırgızistan-Türkiye Manas Üniversitesi Yayınlarl: 86, (pp. 313322). Bişkek.

Yücel, T., Mandac1, P. E., \& Kurt, G. (2007). İşletmelerin Finansal Risk Yönetimi ve Türev Ürün Kullanımı: İMKB 100 Endeksinde Yer Alan İşletmelerde Bir Uygulama. Muhasebe ve Finansman Dergisi(36), 1-9.

Zor, İ., \& Akın, A. (2008). Stratejik Projeksiyonlar Bağlamında KOBİlerde Finansman Araçları Kullanımı. Afyon Kocatepe Üniversitesi, I.I.B.F. Dergisi, X(1), 177-199. 